\title{
Training improved the note taking skill of nursing students in Aksum University; northern Ethiopia: a classroom-based action research
}

\author{
Awole Seid ${ }^{{ }^{*}}$ and Hafte Teklay ${ }^{2}$
}

\begin{abstract}
Objective: Note taking is an effective strategy to improve students' learning. It is considered that very few learners are fit enough for basic note taking skill. Thus, this study was aimed to assess note taking skill and motivation for learning of nursing students and to take action on the identified gaps.

Results: The mean note taking skill score is $22.95 \pm 4.766$. The study demonstrates $9.1 \%$ of students had good note taking skill but 54.5 and $36.4 \%$ had moderate and poor note taking skills respectively. Regarding learning motivation, 13.6\% had motivation and the rest 68.2 and $18.2 \%$ had moderate and poor motivation for learning to be a nurse respectively. On the items used to examine motivation, $54.1 \%$ of students were less motivated to ask questions in classroom though clarification is needed. Reasons for poor note taking showed 68.2 and $27.3 \%$ responded due to "most faculties are simply reading from the slides" and "students are confident that instructors will give slide copies later" respectively were the two main cited reasons respectively. Training nursing students about note taking techniques has made considerable impact on student's learning behavior.
\end{abstract}

Keywords: Note taking, Motivation, Nursing, Students, Ethiopia

\section{Introduction}

Note taking is advantageous to the students to understand lecture points and to improve recalling of information later. It increases class attention, active engagement in classes, clarification and paraphrasing of confusing points and their performance. Note taking is also useful as a reference material for a learner to review it when necessary [1].

It is considered that very few learners are fit enough for basic note taking skill. As taking notes is fast highlighting of information pointed out in lectures; it requires knowledge and skill to do so. Taking note involves condensed note of points, symbolization, relating to real life/

\footnotetext{
*Correspondence: sawlayehu@gmail.com

${ }^{1}$ Department of Nursing, Bahir Dar University, P.O. Box 79, Bahir Dar, Ethiopia

Full list of author information is available at the end of the article
}

environment and summarizing for easy memory of information [2].

Taking notes with students own words enable them to engage in all classroom activities. Various research studies on note taking produces evidences against all trends that lets students passive in classroom [3].

Research findings showed that there is strong and positive relationship between quality of note taking and academic performance. Not only in higher institution, note taking, can be successfully taught to children as young as elementary age. Moreover, many researchers assert that students can become more effective note takers by receiving systematic note taking training by experts, and by practicing and comparing their own notes with peers' [4].

The poor quality of student notes may reflect not only a lack of skills necessary to take accurate and complete notes but also the complexity of the task. Note taking 
involves listening to new and often unfamiliar information, transcribing that information quickly enough to keep pace with the lecture, and deciding how to organize the material to reflect the relationships stated by the speaker [5]. Several studies indicate that students have difficulty organizing lecture material and identifying main points. Furthermore, students say they experience the most difficulty with lecturers that speak too quickly or inaudibly, fail to present a clear outline of the beginning of the lecture, or fail to signal important information [6].

Instructors who thought nursing students in Aksum University complained about a gap on note taking during lecture. As the same time, students often failed the exam if the exam questions are extracted out of the handout/ reading material given but discussed in the classroom. In addition, students look passive in class even if frequent questions are forwarded. One of our research team member explained students were following him like "film actor" while lecturing. He means they did not take notes at all.

This is very challenging on the students' academic success that in turn would negatively affect student's competency of learning. Thus, this action research is conducted aiming at improving the note taking skill of nursing students and contribute in enhancing students academic performance. One of the means of achieving this is through action research defined as a systematic research process that can be articulated by the researcher, involving data collection and analysis as well as reflection and discussion with co-researchers or others for the purpose of making change in situation overtime. Even though the early nursing theorist Betty Newman advocated early for use of action research in nursing due to the direct connection to practice, limited to use is evident in nursing education [7].

\section{Main text}

\section{Methods and materials}

The study was conducted at third year nursing department students in Aksum University on March, 2016. The tool used to assess note taking skill and motivation is adopted from university of Houston counseling service (webmaster@uhcl.edu). The questionnaire has two parts. Note taking and motivation. Each part has 8 questions with a maximum score of 32 . A self-administered anonymous questionnaire was prepared and distributed for each student. Data is analyzed using SPSS version 20. The result is described using texts, tables and graphs as necessary. The association between variables was measured using correlation $(r)$ as it is appropriate for two continuous exposure and outcome variables. Moderate correlation is present if $r>0.5$ and statistically significant if the $p$ value is $<0.05$.

\section{Operational definition}

- Good note taking skill: students score 29-32 points.

- Moderate note taking skill: students score 21-28 points.

- Poor note taking skill: students score below 20.

- Good motivation: students score 29-32.

- Moderate motivation: students score 21-28.

- Poor motivation: students score below 20 .

\section{Result}

From a total 30 students 22 are participated in the study. The response rate is $100 \%$. The major findings of the study are presented as follows.

From the study participants only one student is female and the rest were males. The level of perceived academic performance shows 16 (72.7\%) perceive as medium level and $6(27.3 \%)$ as high performance but none of them reported as poor achievers.

\section{Note taking skill results}

The mean note taking skill score is $22.95 \pm 4.766$. The minimum and maximum scores students get in note taking skill is 13 and 31 respectively.

As shown above, from the total study participants $36.4 \%$ have poor note taking skills and only $9.1 \%$ have good note taking skills (Fig. 1).

Among the sub questions presented to assess note taking skills of students, students have relatively good behavior with regard to taking notes using outline format except for mind maps $(45.5 \%)$ and a good culture of taking notes while they read supplementary readings (40.9\%). On the other hand, students have poor behavior with regard to "understanding lecture while taking notes during classroom time" and "reviewing notes after class or during the night time".

Finding on reason for poor note taking skill showed, 68.2 and $27.3 \%$ responded due to "most faculties are

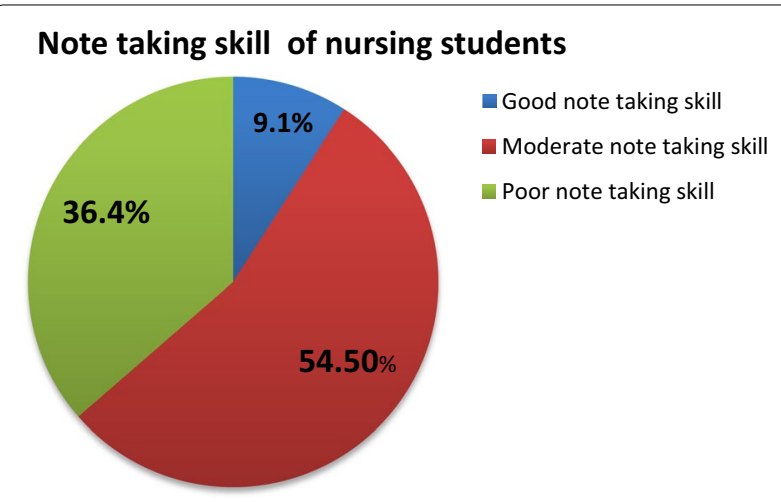

Fig. 1 Distribution of note taking skill of 3rd year nursing students, Aksum University, Northern Ethiopia, 2016 
simply reading from the slides" and due to "students are confident that instructors will give them hard copy slide prints later" are the two main cited reasons respectively.

\section{Motivation level results}

In this regard, the mean motivation score among the study participants are $24 \pm 4.071$ and the minimum and maximum motivation for learning score is 13 and 16 respectively. On the items used to examine motivation, $54.1 \%$ of students were less motivated to ask questions in classroom though clarification is needed.

The finding on motivation reveals $18.2 \%$ have poor motivation and $13.6 \%$ have good motivation for learning in the classroom (Fig. 2).

Correlation finding showed there is statistically significant correlation between motivation and note taking skill of students $(\mathrm{r}=0.663, \mathrm{p}=0.001)$. This also implies that $43.95 \%$ of the variation in score of note taking skill is explained by the difference in motivation status of students $\left(r^{2}=0.439\right)$ (Table 1$)$.

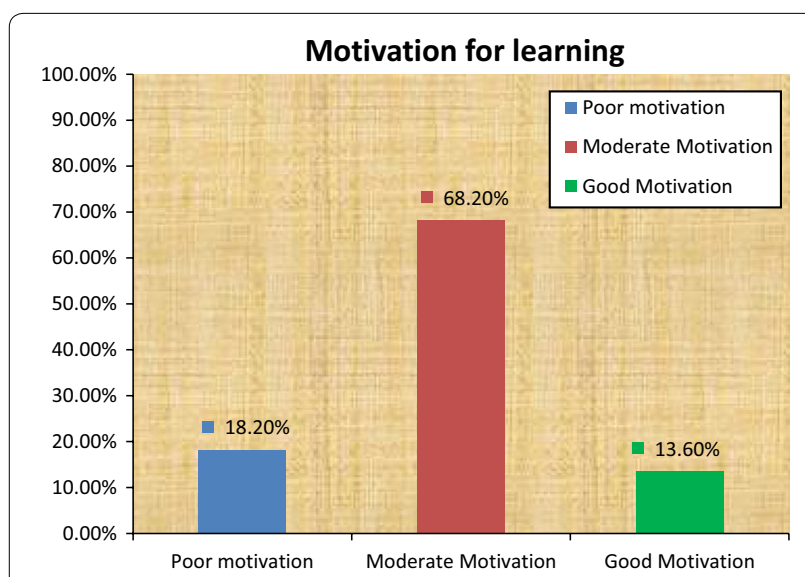

Fig. 2 Distribution of Motivation status of 3rd year nursing students, Aksum University, Northern Ethiopia, 2016

\section{Implementation}

On $18 / 4 / 2016$ at 2.00 p.m. the research team members gave training for 3rd year nursing students about note taking skills. After tutors' give an essay like materials, students were grouped and enabled to do exercises on note taking skill using different techniques. One group presented notes using outline format, another using table, and the remaining using a mind map. Comments were given from peers and HDP candidates as well.

The study finding is presented to the department staffs and reached consensus on discontinuing giving handouts for courses with adequate references and to minimize the number of slides. Additionally, instructors should prepare in advance and promote students engagement in class by transferring the responsibility for learning to them.

\section{Evaluation}

As we gather from the instructor more students are taking notes in classroom. The students need continuous monitoring for the coming year too and hoping that discontinuing handouts will provoke them to take notes in classroom and while reading books.

The intervention promotes students for independent learning (self-directed learning) through engagement in classroom and the students highlight main points in class and further expand their knowledge through reading different references. The intervention aids student to exercise time saving technique of note taking during lecture time and reading texts. After continuous evaluation if the problem is recurring the study may be repeated and other ways interventions will be designed.

\section{Discussion}

This study provides a glance view of the note taking skills status of nursing students with small sample size. The implications of this research finding on practice suggest there will be potential impact on quality of health care at the end unless promptly intervened.

Table 1 Action plan to improve note taking skill of nursing students, Aksum University, northern Ethiopia, 2016

\begin{tabular}{|c|c|c|c|c|c|}
\hline Problem & Activity & Responsible body & Time frame & Resources & $\begin{array}{l}\text { Monitoring } \\
\text { and evaluation } \\
\text { strategy }\end{array}$ \\
\hline Poor note taking skill & $\begin{array}{l}\text { Training on note taking } \\
\text { skills } \\
\text { Discontinuing giving } \\
\text { handouts for courses } \\
\text { with adequate refer- } \\
\text { ences } \\
\text { Advising instructors to } \\
\text { minimize slides and } \\
\text { prepare in advance } \\
\text { before class }\end{array}$ & $\begin{array}{l}\text { Research team mem- } \\
\text { bers } \\
\text { Instructors } \\
\text { Nursing department }\end{array}$ & $\begin{array}{l}\text { 18/4/2016, } 2.00 \text { p.m. } \\
\text { Starting from next year } \\
(2017)\end{array}$ & $\begin{array}{l}\text { LCD projector, tea } \\
\text { break, flip chart, } \\
\text { marker } \\
\text { Books } \\
\text { Modules }\end{array}$ & $\begin{array}{l}\text { Observing change } \\
\text { of behavior in con- } \\
\text { secutive classes after } \\
\text { training } \\
\text { Including questions } \\
\text { that are not given } \\
\text { by handout but dis- } \\
\text { cussed in classroom }\end{array}$ \\
\hline
\end{tabular}


The finding on note taking skill also suggests the need to adopt experiences from local and other international perspectives. As most students face difficulty of inquiring at classroom the university should cultivate the value of freedom of speech in schools. Modification of interventions may required if the study produces similar result at college level like adopting as a policy to train students about note taking and other necessary skills may be necessary. Furthermore, conducting classroom based action research should be one of educational responsibility of faculties.

\section{Conclusion}

Note taking facilitates both recall of factual material and the synthesis and application of new knowledge, particularly when notes are reviewed prior to exams. It enables students to actively engage in learning process. Creating awareness about the benefit of note taking and training students about different techniques of note taking has made considerable impact on student's learning behavior.

\section{Limitations}

The limitation of this study is small sample size and the impact on training wasn't assessed continuously. Therefore, studying with large sample size on longitudinal method is recommended.

\section{Abbreviations}

HDP: Higher Diploma Program; SPSS: Software Program for Social Sciences.

\section{Authors' contributions}

AS initiated the idea, carried out the study, and involved in drafting the manuscript. HT contributed to the pre-test of the tool, statistical analysis, and writing the manuscript. Both authors involved in the intervention (training) session. Both authors read and approved the final manuscript.

\section{Author details}

${ }^{1}$ Department of Nursing, Bahir Dar University, P.O. Box 79, Bahir Dar, Ethiopia. ${ }^{2}$ Department of Biomedical Sciences, Aksum University, Aksum, Ethiopia.

\section{Acknowledgements}

Though the research was not funded, we thank Aksum University department of nursing for facilitating the training site and integrating the result into the teaching learning process.

\section{Competing interests}

The authors declare that they have no competing interests.

\section{Availability of data and materials}

All the data supporting the findings is contained within the manuscript.

\section{Consent for publication}

Not applicable.

\section{Ethics approval and consent to participate}

Verbal consent was taken from students to ensure their volunteerism to participate in the study. The study was approved by Institutional Review Board (IRB) of Aksum University College of Health Sciences. As the study is small scale, non intensive and not clinical trial permission from the department, notifying the IRB and verbal consent from students were enough to conduct the study.

\section{Funding}

There is no funding of the study.

\section{Publisher's Note}

Springer Nature remains neutral with regard to jurisdictional claims in published maps and institutional affiliations.

Received: 21 January 2018 Accepted: 19 July 2018

Published online: 02 August 2018

\section{References}

1. Piolat A, Olive T, Kellogg RT. Cognitive effort during note taking. Appl Cognit Psychol. 2005;1 9(3):291-312.

2. DeZure D, Kaplan M, Deerman MA. Research on student notetaking: implications for faculty and graduate student instructors. CRLT Occasional Papers No. 16. 2001

3. Ruhl KL, Suritsky S. The pause procedure and/or an outline: effect on immediate free recall and lecture notes taken by college students with learning disabilities. Learn Disabil Q. 1995;18(1):2-11.

4. Lee P-L, Wang C-L, Hamman D, Hsiao C-H, Huang C-H. Notetaking instruction enhances students'science learning. Child Dev Res. 2013. https://doi. org/10.1155/2013/831591.

5. Rogers JW, Cox JR. Integrating a single tablet PC in chemistry, engineering, and physics courses. J Coll Sci Teach. 2008;37(3):34.

6. Boch F, Piolat A, editors. Note taking and learning a summary of research. In: Writing. Citeseer; 2005.

7. Moch SD, Vandenbark RT, Pehler S-R, Stombaugh A. Use of action research in nursing education. Nurs Res Pract. 2016. https://doi. org/10.1155/2016/8749167

Ready to submit your research? Choose BMC and benefit from:

- fast, convenient online submission

- thorough peer review by experienced researchers in your field

- rapid publication on acceptance

- support for research data, including large and complex data types

- gold Open Access which fosters wider collaboration and increased citations

- maximum visibility for your research: over 100M website views per year

At BMC, research is always in progress.

Learn more biomedcentral.com/submissions 